\title{
Wojciech Wydmański
}

Uniwersytet Śląski w Katowicach e-mail: wojciechw1998@interia.pl

ORCID: 0000-0002-9619-5062

DOI: $10.15290 /$ mhi.2021.20.01.02

\section{Niemiecki kodeks cywilny w pracach Komisji Kodyfikacyjnej nad Kodeksem zobowiązań z 1933 r.}

\begin{abstract}
ABSTRAKT
Celem niniejszej pracy jest omówienie wykorzystania przez Komisję Kodyfikacyjną II Rzeczypospolitej niemieckiego kodeksu cywilnego z 1896 r. (BGB) w pracach nad Kodeksem zobowiązań z 1933 r. Tematyka kodyfikacji i unifikacji prawa prywatnego w okresiemiędzywojennymcieszysięwielkimzainteresowaniemwśródhistorykówprawa, a także znawców komparatystyki prawniczej. Wynika to z faktu, iż proces unifikacji i kodyfikacji prawa zobowiązań w II Rzeczypospolitej zakładał opracowanie kodeksu łączącego elementy wszystkich ustaw dawnych państw zaborczych. Dzięki temu polski kodeks zobowiązań nie zaliczał się ani do systemu romańskiego ani germańskiego. Na szczególną uwagę zasługuje wykorzystanie przez członków Komisji Kodyfikacyjnej BGB. W pracy zostanie zaprezentowany wykaz przepisów kodeksu zobowiązań, które były wzorowane wyłącznie na niemieckiej ustawie lub na BGB oraz innych kodeksach. Ponadto zostanie zaprezentowane wykorzystanie BGB na wybranych przepisach kodeksu zobowiązań. Przy ustaleniu wpływu BGB na przepisy kodeksu zobowiązań wykorzystana zostanie metoda porównawcza oraz teksty aktów normatywnych, materiały legislacyjne oraz literatura prawnicza. Szczególnie pomocne będzie uzasadnienie projektu kodeksu zobowiązań autorstwa referenta Romana Longchamps Bérier. Tematyka poruszona w pracy może okazać się atrakcyjna dla naukowców polskich oraz niemieckich, badających wpływ BGB na rozwój polskiego prawa obligacyjnego.
\end{abstract}




\section{ABSTRACT \\ The German Civil Code in the Work of the Codification Committee on the Code of Obligations of 1933}

The work aims to discuss the use of the German Civil Code from 1896 (BGB) by the Codification Commission in the work on the Code of Obligations from 1933. The subject of codification and unification of private law in the interwar period is of great interest to historians of law. It is also an issue for experts in comparative legal studies. This is since the process of unification and codification of the law of obligations in the Second Polish Republic assumed the development of a code combining elements of all laws of the former partitioning states. As a result, the Polish Code of Obligations does not belong to either the Romanesque or the Germanic system. Particularly noteworthy is the use by members of the BGB Codification Committee. The work will present a list of the provisions of the Code of Obligations that were modeled only on the German law or on the BGB and other codes. Additionally, the use of BGB will be presented on selected regulations of the Code of Obligations. When determining the impact of BGB on the rules of the Code of Obligations, a comparative method and the texts of normative acts, legislative materials, and legal literature will be used. The justification for the draft Code of Obligations by Roman Longchamps de Bérier will be particularly helpful. The subject matter raised in the paper may turn out to be attractive to Polish and German researchers studying the impact of the BGB on the development of Polish obligation law.

Słowa kluczowe: kodeks zobowiązań, unifikacja, kodyfikacja, BGB, Komisja Kodyfikacyjna, dwudziestolecie międzywojenne, komparatystyka prawnicza

Key words: code of obligations, unification, codification, BGB, Codification Commission, interwar period, legal comparative 


\section{Uwagi wstępne}

Tematyka kodyfikacji prawa prywatnego w czasach II Rzeczpospolitej od lat cieszy się zainteresowaniem wśród historyków prawa ${ }^{1}$. Jest to bowiem okres, w którym polski prawodawca stanął przed wielkim wyzwaniem, jakim było ujednolicenie systemu prawnego. Choć w 1918 r. Polska odzyskała niepodległość, to jednak nadal na ziemiach byłych zaborów obowiązywało prawo państw zaborczych. Konieczność kodyfikacji i unifikacji prawa była jednym z najważniejszych zadań w procesie integracji kraju ${ }^{2}$. W związku z potrzebami gospodarczymi i społecznymi na szczególną uwagę zasługiwało prawo zobowiązań3 ${ }^{3}$.

1 Zob. Z. Radwański, Kształtowanie się polskiego systemu prawnego w pierwszych latach II Rzeczypospolitej, „Czasopismo Prawno-Historyczne” 1969, t. 21, z. 1; S. Grodziski, Prace nad kodyfikacja i unifikacja polskiego prawa prywatnego (1919-1947), „Kwartalnik Prawa Prywatnego” 1992, z. 1-4; idem, $Z$ dziejów unifikacji prawa prywatnego, „Czasopismo Prawo-Historyczne” 1985, z. 2; M. Pietrzak, Z problematyki kodyfikacji prawa w II Rzeczypospolitej, [w:] Partykularyzm a unifikacja prawa w Polsce (XV-XX w.), red. T. Maciejewski, Gdańsk 1994; A. Lityński, Pót wieku kodyfikacji prawa $w$ Polsce (1919-1969), Tychy 2001; idem, Dluga droga kodyfikowania prawa cywilnego w Polsce, „Czasopismo Prawno-Historyczne” 2001, z. 1; L. Górnicki, Prawo cywilne w pracach Komisji Kodyfikacyjnej, Wrocław 2000; idem, Zagadnienia systematyki kodyfikacji prawa cywilnego i handlowego w pracach Komisji Kodyfikacyjnej (1919-1939), „Kwartalnik Prawa Prywatnego” 2004, z. 3.

2 Zob. L. Górnicki, Prawo jako czynnik integracji państwa w latach II Rzeczypospolitej, „Acta Universitatis Wratislaviensis. Prawo" 2011, s. 111-114.

3 L. Górnicki, Prawo cywilne w pracach..., s. 397-462; idem, Wpływ obcych ustawodawstw i doktryny prawa na polska kodyfikacje prawa prywatnego w Drugiej Rzeczypospolitej, „Zeszyty Prawnicze TBSP UJ" 2005, z. 13; idem, Metoda opracowania i koncepcja kodeksu zobowiązań z 1934 roku, „Acta Universitatis Wratislaviensis. Prawo” 2008; idem, Zasada uspołecznienia pewnych stosunków umownych $w$ kodeksie zobowiązań $z 1933$ roku, [w:] Zasady prawne $w$ dziejach prawa publicznego i prywatnego, red. M. Podkowski, Wrocław 2015; idem, Godność osobista pracownika pod rzadami kodeksu zobowiązań z 1933 r., [w:] Honor, cześć, godność: aspekty historyczno-prawne, red. P. Wiązek, Wrocław 2016; G. Jędrejek, Polski kodeks zobowiązań z 1933 roku powstanie, źródła, znaczenie dla europejskiego prawa obligacyjnego, „Roczniki Nauk Prawnych” 2001, t. 11, z. 1; A. Stawarska-Rippel, Kodeks zobowiazań w pierwszych latach Polski Ludowej, „Kwartalnik Prawa Prywatnego” 2004, nr 3; A.M. Falkowska [Moszyńska], Wpływ praw obcych na kodeks zobowiązań z 1933 roku na podstawie wybranych instytucji prawa obligacyjnego, [w:] Korzenie i tradycje wspótczesnego prawa cywilnego w zjednoczonej Europie, red. A. Karabowicz, M. Strusa, Kraków 2005; eadem, Charakter i zakres odpowiedzialności sprzedawcy z tytułu rękojmi w kodeksie zobowiązań z 1933 r., „Zeszyty Naukowe Wyższej Szkoły Suwalsko-Mazurskiej im. Papieża Jana Pawła II w Suwałkach” 2008, t. 9, nr 17; eadem, O pracach kodyfikacyjnych słów kilka: prace nad kształtem instytucji rękojmi w kodeksie zobowiązań, [w:] Świat, Europa, mała Ojczyzna, studia ofiarowane profesorowi Stanisławowi Grodziskiemu w 80-lecie urodzin, red. M. Małecki, Bielsko-Biała 2009; J. Halberda, Instytucja niesłusznego zbogacenia w Kodeksie zobowiąań z 1933 r. na tle współczesnych kodyfikacji, „Krakowskie Studia z Historii Państwa i Prawa” 2012, nr 5; idem, Nienależne świadczenie w polskim Kodeksie zobowiazań z 1933 r. na tle porównawczym, „Krakowskie Studia z Historii Państwa i Prawa” 2016, t. 9, z. 1; J. Kola, Działalność Komisji Kodyfikacyjnej w obszarze prawa zobowiazań. Refleksje z okazji 80 rocznicy Kodeksu zobowiazań, „Palestra” 2013, nr 9-10; J.S. Petraniuk, Charakterystyka polskiego prawa zobowiązań okresu II Rzeczypospolitej, [w:] Synteza Prawa Polskiego 1918-1939, red. T. Guz, J. Głuchowski, M.R. Pałubska Warszawa 2013; W. Dajczak, Kodeks zobowiązań jako lekcja metody prawnoporównawczej, „Kwartalnik Prawa Prywatnego” 2014, z. 4; M. Derek, Indywidualizm czy socjologizm? Zasada swobody umów w projektach polskiego kodeksu zobowiąań z 1933 roku na tle 
Prace nad kodyfikacją nowego prawa rozpoczęły się jeszcze przed odzyskaniem niepodległości w ramach Departamentu Sprawiedliwości utworzonego przez Tymczasową Radę Stanu i działającego następnie przy Radzie Regencyjnej ${ }^{4}$. Po odzyskaniu niepodległości w listopadzie 1918 r. kompetencję w zakresie opracowywania projektów legislacyjnych uzyskało Ministerstwo Sprawiedliwości. Jednakże bez wątpienia największą rolę w opracowywaniu projektów ustaw odegrała Komisja Kodyfikacyjna, która została utworzona na mocy ustawy z 3 czerwca 1919 r. ${ }^{5}$ Skupiała najwybitniejszych przedstawicieli nauki, ale także praktyki prawa ${ }^{6}$

Zadanie, przed jakim stanęli członkowie Komisji Kodyfikacyjnej, choć Z uwagi na ogrom pracy oraz różnorodność ówczesnego sytemu prawnego odrodzonej Polski nie było łatwe, to jednak dawało im dość duże możliwości oraz swobodę w przygotowywaniu projektów ustaw. Jak przyjmuje się w literaturze ${ }^{7}$,

porównawczym, „Czasopismo Prawno-Historyczne” 2015, t. 67, z. 2; D. Haponiuk, Uwagi o pracach nad polskim kodeksem zobowiązań z 1933 r. ze szczególnym uwzględnieniem zasady stuszności, „Miscellanea Historico-Iuridico” 2018, t. 17, z. 1.

4 R. Jastrzębski, Wplyw polskiej tradycji prawnej na kodyfikację prawa prywatnego (1919-1939), [w:] Między tradycja a nowoczesnością. Prawo polskie w 100-lecie odzyskania niepodległości, red. Ł. Pisarczyk, Warszawa 2019, s. 254.

5 Ustawa z dnia 3 czerwca 1919 r. o powołaniu Komisji Kodyfikacyjnej (Dz.Pr.P.P. 1919 nr 44, poz. 315). Warto zauważyć, że powołanie Komisji Kodyfikacyjnej II RP na podstawie ustawy podnosiło rangę tego organu. W porównaniu do innych komisji z czasów późniejszych, jak Komisja Kodyfikacyjna przy Ministrze Sprawiedliwości z 1956 r. czy Komisja Kodyfikacyjna Prawa Cywilnego z lat 1996-2015, które zostały powołane na mocy zarządzeń, uchwały i rozporządzenia Rady Ministrów Komisja z okresu międzywojennego odgrywała wyjątkową ważną rolę w procesie legislacyjnym. Zob. Zarządzenie nr 227 Prezesa Rady Ministrów z dnia 23 sierpnia 1956 r. w sprawie powołania Komisji Kodyfikacyjnej (M.P. 1956 nr 70, poz. 856); Uchwała Rady Ministrów nr 109/96 z dnia 17 września 1996 r.; Rozporządzenie Rady Ministrów z dnia 22 kwietnia 2003 r. w sprawie organizacji i trybu działania Komisji Kodyfikacyjnej Prawa Cywilnego.

6 F.X. Fierich, Komisja Kodyfikacyjna w Rzeczypospolitej Polskiej, „Ruch Prawniczy, Ekonomiczny i Społeczny" 1925, z. 3; K. Sójka-Zielińska, Organizacja prac nad kodyfikacja prawa cywilnego w Polsce międzywojennej, „Czasopismo Prawno-Historyczne” 1975, t. 27, z. 2; S. Grodziski, Komisja Kodyfikacyjna Rzeczypospolitej Polskiej, „Czasopismo Prawno-Historyczne” 1981, t. 31, z. 2; idem, W osiemdziesięciolecie Komisji Kodyfikacyjnej (Geneza i struktura), „Państwo i Prawo” 2000, z. 4; A. Lityński, Wydział Karny Komisji Kodyfikacyjnej II Rzeczypospolitej. Dzieje prac nad częścią ogólnq kodeksu karnego, Katowice 1991; M. Mohyluk, Porzadkowanie prawa w II Rzeczypospolitej: Komisja Kodyfikacyjna i Rada Prawnicza, „Czasopismo Prawno-Historyczne” 1999, z. 1-2; L. Górnicki, Prawo cywilne w pracach...; idem, Organizacyjne zagadnienia kodyfikacji prawa handlowego w Komisji Kodyfikacyjnej II RP (1919-1939), „Acta Universitatis Wratislaviensis. Prawo” 2003; idem, Komisja Kodyfikacyjna II RP: pozycja ustrojowa, podejmowanie decyzji, „Acta Universitatis Wratislaviensis. Prawo" 2019; idem, Rola parlamentu w powstaniu i działalności Komisji Kodyfikacyjnej II RP w zakresie kodyfikacji prawa prywatnego, [w:] Zgromadzenia stanowe i organy przedstawicielskie $w$ dziejach; Ksiega jubileuszowa dedykowana Profesorowi Marianowi Ptakowi, red. J. Koredczuk, P. Wiązek, Wrocław 2020; S. Płaza, Historia prawa w Polsce na tle porównawczym cz. III. Okres międzywojenny, Kraków 2001; idem, Kodyfikacja prawa w Polsce międzywojennej, „Czasopismo Prawno-Historyczne" 2005, z. 1; E. Borkowska-Bagińska, O doświadczenia kodyfikacji prawa cywilnego w II Rzeczypospolitej dla współczesnego ustawodawcy, „Czasy Nowożytne” 2002, t. 12; M. Mazuryk, I. Sadowski, Organizacja i funkcjonowanie komisji kodyfikacyjnej prawa cywilnego w latach 1919-1989. Zarys problematyki, ,Rocznik Nauk Prawnych” 2013, nr 23, z. 1. 
zwyciężyła jedna z kilku koncepcji, zakładająca opracowanie nowego krajowego prawa, odrzucając przy tym możliwość recepcji zarówno któregoś z praw państw zaborczych, jak i dawnego prawa polskiego. Należy przypomnieć, iż członkowie Komisji Kodyfikacyjnej w opracowywaniu projektów aktów normatywnych nie byli związani narodowym dorobkiem prawnym, rozumianym jako prawo I Rzeczypospolitej. Było ono archaiczne już w XIX w. o czym ówcześni zdawali sobie sprawę ${ }^{8}$. Jednakże, choć starano się odejść od narzuconych w wyniku zaborów praw i stworzyć własne oryginalne rozwiązania legislacyjne, to przecież nie można było całkowicie zerwać $\mathrm{z}$ dorobkiem państw zaborczych ${ }^{9}$. Przede wszystkim dlatego, że prawo to przyjęło się w polskim społeczeństwie, a także dlatego, że na terenie Polski obowiązywały ustawy należące zarówno do systemu germańskiego (niemiecki kodeks cywilny z 1896 r. i austriacki kodeks cywilny z 1811 r.) jak i romańskiego (Kodeks Napoleona z 1804 r.), a więc największe osiągnięcia europejskiej cywilistyki XIX w. Fakt, że było to prawo narzucone $\mathrm{w}$ wyniku wydarzeń historycznych, nie przeszkadzał w jego wykorzystaniu przy opracowywaniu projektów ustaw. Pogląd ten był obecny od samego początku działalności Komisji. Na pierwszym inauguracyjnym posiedzeniu Komisji Kodyfikacyjnej 10 listopada 1919 r. kilku prelegentów wskazywało na sposobność korzystania z dorobku praw obcych. Warto przywołać słowa Marszałka Sejmu (Ustawodawczego) Wojciecha Trąmpczyńskiego (wieloletniego adwokata i doktora nauk prawnych) ${ }^{10}$ :

Wolni zatem będziecie od więzów historycznych, będziecie mogli wlać $\mathrm{w}$ formy ustawowe, które według słów poety (Goethego) - razem z nami się zrodziło. (...) Po za tem jednak byłoby błędem, gdybyśmy, goniąc za rzekomą oryginalnością narodową, nie korzystali w pełnej mierze $\mathrm{z}$ nauki innych narodów lub $\mathrm{z}$ doświadczeń, $\mathrm{w}$ innych krajach poczynionych ${ }^{11}$.

Jeszcze lepsze wydają się słowa ks. Adam Czartoryskiego przywołane przez przewodniczącego Komisji F. X. Fiericha jeszcze przed powstaniem Komisji,

8 A. Moniuszko, P. Z. Pomianowski, Zerwana więź. Tradycje dawnego prawa polskiego w XIX i XX wieku, [w:] Między tradycją a nowoczesnością. Prawo polskie w 100-lecie odzyskania niepodległości, red. Ł. Pisarczyk, Warszawa 2019, s. 386-389.

9 Jak wskazał przewodniczący Sekcji Prawa Cywilnego Komisji Kodyfikacyjnej W. L. Jaworski: „Musimy mieć ambicję, żeby stworzyć kodeks, któryby nie tylko odpowiadał aktualnym stosunkom, ale także miał szanse utrzymania się przez pewien dłuży czas. Gdybyśmy poszli za objawianem przez niektórych prawników zdaniem, że wystarczy zmodyfikować i dostosować do polskich potrzeb jeden ze znakomitych obcych kodeksów cywilnych, stworzylibyśmy mojem zdaniem kodeks, któryby od razu był anachronizmem. Nie przychylam się przeto do tego kierunku i idę trudniejszą drogą stworzenia kodeksu, który bezpośrednio wspierał się na panujących obecnie stosunkach (...). Zob. W.L. Jaworski, Nowożytny Kodeks Cywilny. Referat na Komisji Kodyfikacyjnej Rzeczypospolitej Polskiej dnia 6 grudnia 1921 r., Kraków 1922, s. 5-6. Por. I. Koschembahr-Łyskowski, W sprawie naszego prawa cywilnego, Warszawa 1925, s. 2 i n.

10 Z. Kaczmarek, Marszałkowie Senatu II Rzeczypospolitej, Warszawa 1992, s. 21-24.

11 Komisja Kodyfikacyjna Rzeczypospolitej Polskiej. Dział ogólny 1921, t. 1, z. 1, s. 17. 
a które są często cytowane w pracach historycznoprawnych ${ }^{12}$ : „Nie ma hańby, przeciwnie, jest powinnością korzystać z doświadczenia drugich, czerpać wszędzie, co jest dobrego i sobie przyswajać poprawy, dodatki, doskonalenia"13.

Korzystanie $\mathrm{z}$ dorobku prawnego państw obcych w pracach nad unifikacją prawa zobowiązań było przedmiotem badań m.in. Leonarda Górnickiego ${ }^{14}$ i Anny M. Moszyńskiej [Falkowskiej] ${ }^{15}$. Na szczególną uwagę i uznanie zasługują prace pierwszego autora poświęcone kodyfikacji i unifikacji prawa prywatnego $\mathrm{w}$ okresie międzywojennym. Badanie komparatystyczne nad przenikaniem się norm między systemami prawnymi jest ważnym i ciekawym tematem badawczym w szczególności w pracach nad dziejami ewolucji oraz unifikacji i kodyfikacji prawa. Pozwala bowiem zrozumieć tożsamość instytucji prawnych oraz ich wpływ na rozwój poszczególnych systemów prawnych. Odgrywa także istotną rolę w studiach prawniczych ${ }^{16}$.

Zanim przejdziemy do dalszych rozważań, warto spróbować określić znaczenie terminów: unifikacja i kodyfikacja. Obydwa często występują w pracach prawniczych i odnoszą się do procesu stanowienia prawa ${ }^{17}$. Często można

12 Zob. L. Górnicki, Wpływ obcych ustawodawstw i doktryny prawa na polską kodyfikacje prawa prywatnego Drugiej Rzeczypospolitej, „Zeszyty Prawnicze TBSP UJ” 2005, z. 13, s. 59; R. Jastrzębski, op. cit., s. 257.

13 F.X. Fierich, Rzut oka na najważniejsze zadania prac kodyfikacyjnych, „Kwartalnik Prawa Cywilnego i Karnego" 1919, R. II, s. 457-458.

14 Zob. L. Górnicki, Prawo cywilne w pracach..., s. 460-462; idem, Wpływ obcych ustawodawstw i doktryny prawa na polska kodyfikacje prawa prywatnego Drugiej Rzeczypospolitej, „Zeszyty Prawnicze TBSP UJ" 2005, z. 13, s. 63-67; idem, Pogranicza systemów prawnych, w szczególności pozaborowych, w pracach nad kodyfikacjami prawa cywilnego i handlowego w II RP, „Acta Universitatis Wratislaviensis. Prawo" 2017, s. 136-140.

15 A. Falkowska-Szemta [Moszyńska], Regulacja $w$ zakresie odpowiedzialności sprzedawcy $z$ tytuły rękojmi za wady i braki przedmiotu świadczenia w austriackim kodeksie cywilnym z 1811 r. (ABGB) i jego wpływ na przepisy polskiego kodeksu zobowiązań z 1933 r., „Zeszyty Naukowe Wyższej Szkoły Suwalsko-Mazurskiej im. Papieża Jana Pawła II w Suwałkach” 2006, t. 7, nr 14; eadem, Wpływ praw obcych...; eadem, Szwajcarski kodeks zobowiązań w pracach Komisji Kodyfikacyjnej Rzeczypospolitej Polskiej w okresie dwudziestolecia międzywojennego, ,Studia Iuridica Toruniensia” 2008, t. 4.

16 Zob. W. Hug, The history of comparative law, "Harvard Law Review" 1932, t. 45, nr 6, s. 1028 i n.; M. Schmitthoff, The science of comparative law, "The Cambridge Law Journal” 1939, t. 7, nr 1, s. 99 i n.; H J. Ault, M.A. Glendon, The importance of comparative law in legal education: United State Goals and Methods of legal comparison, "Journal of Legal Education" 1976, t. 27, nr 4, s. 599; K. Zweigert, H. Kötz, An Introduction to Comparative Law. Volume I: The Framework, AmsterdamNew York-Oxford 1977, s. 10-22; J. Gordley, Comparative Legal Research: Its Function in the Development of Harmonized Law, "The American Journal of Comparative Law" 1995, t. 43, nr 4, s. 556 i n.; idem, Comparative Law and Legal History, [w:] The Oxford Handbook of Comparative law, red. M. Reimann, R. Zimmermann, New York 2006, s. 768; W. Dajczak, op. cit., s. 829-840; J. Rudnicki, Prawo cywilne ,własne” i ,obce” sto lat temu oraz współcześnie, [w:] Między tradycją a nowoczesnością. Prawo polskie w 100-lecie odzyskania niepodległości, red. Ł. Pisarczyk, Warszawa 2019.

17 S. Salmonowicz, Kodyfikacje i myśl kodyfikacyjna XVII i XVIII wieku, [w:] Dzieje kodyfikacji prawa. Materiały na konferencję historyków prawa w Karpaczu, Poznań 1974, s. 143-146; W. Uruszczak, Europejskie kodeksy prawa doby renesansu, „Czasopismo Prawno-Historyczne” 1988, t. 40, z. 1, s. 60-61; A. Rosett, Unification, Harmonization, Restatement, Codification and Reform in International Commercial Law, “The American Journal of Comparative Law” 1992, t. 40, nr 3, s. 685-688; 
zauważyć, że używane są w sposób zamienny. Ich znaczenie było różne w zależności od epoki historycznej ${ }^{18}$. Mając to na uwadze oraz tematykę niniejszej pracy, przez kodyfikację będziemy rozumieć proces zebrania i usystematyzowania norm poszczególnej gałęzi prawa w jednym akcie normatywnym (kodeksie). Z kolei unifikacja odnosi się do procesu ujednolicenia (harmonizacji) systemu prawnego w celu usunięcia odrębności, partykularyzmów oraz wiążących się z tym kolizji. W niniejszej pracy właściwym pojęciem będzie unifikacja.

\section{BGB w pracach Komisji Kodyfikacyjnej}

Jednym z największych osiągnięć unifikacji prawa prywatnego II RP był Kodeks zobowiązań z 1933 r. ${ }^{19}$ Nie tylko ze względu na nowoczesne jak na owe czasy rozwiązania, ale także dlatego, że zachował równowagę pomiędzy wpływami dawnych kodeksów cywilnych obowiązujących na ziemiach polskich. Twórcy uznali bowiem, iż należy najpierw zunifikować prawo obligacyjne, a następnie włączyć je do przyszłego kodeksu cywilnego. Takie stanowisko przyjęto po opublikowaniu projektu prawa zobowiązań autorstwa Ernesta Tilla i innych autorów na posiedzeniu Sekcji Prawa Cywilnego Komisji Kodyfikacyjnej 8 kwietnia 1923 r. $^{20}$ Pogląd członków Komisji Kodyfikacyjnej $\mathrm{w}$ jakiejś mierze przypomina wcześniejsze rozwiązania szwajcarskie. W 1881 r. szwajcarskiemu prawodawcy udało się opracować prawo o zobowiązaniach. Po uchwaleniu 1907 r. Kodeksu cywilnego (ZGB) i jego wejściu w życie w 1912 r. kodeks zobowiązań został utrzymany w mocy jako księga piąta nowego kodeksu ${ }^{21}$.

S. Sucharitkul, Unification of Private Law and Codification of International Law, "Uniform Law Review" 1998, t. 3, z. 2-3, s. 695 i n.; E. Borkowska-Bagińska, Między zbiorem a kodeksem. Refleksje o kodyfikacji i myśli kodyfikacyjnej Oświadczenia, [w:] Historia integra. Księga pamiątkowa ofiarowana prof. Stanisławowi Salmonowiczowi w siedemdziesięciolecie urodzin, red. D. Jancka, R. Łaszewski, Toruń 2001, s. 93; W. Szafrański, Pojęcie kodyfikacji w ujęciu historycznym, [w:] Prawo wobec wyzwań współczesności, t. 2, red. P. Wiliński, Poznań 2005, s. 108-113.

18 Jak wskazał L. Górnicki oraz A. Lityński współcześnie unifikację (określaną czasem jako harmonizacja) uważa się za etap, część procesu kodyfikacji, która ma charakter nadrzędny. Natomiast w okresie międzywojennym uważano odwrotnie. Unifikacja, jako ujednolicenie, zintegrowanie prawa była priorytetem, dlatego najpierw miano dokonać unifikacji, a następnie kodyfikacji. Jak wskazał A. Lityński: „należało prawo najpierw zunifikować (w takich kodeksach jak kodeks zobowiązań), a następnie skodyfikować w jednym kodeksie cywilnym". Zob. A. Lityński, Pół wieku kodyfikacji..., s. 8; L. Górnicki, Prawo cywilne w pracach..., s. 60-69. Por. Z. Sitnicki, Kodyfikacja a unifikacja, „Przegląd Sądowy” 1929 z. 4.

19 Rozporządzenie Prezydenta Rzeczypospolitej z dnia 27 października 1933 r. - Kodeks zobowiązań (Dz.U. $1933 \mathrm{nr}$ 82, poz. 598)

20 L. Górnicki, op. cit., s. 397; A.M. Falkowska [Moszyńska], Szwajcarski kodeks..., s. 58.

21 E.J. Schuster, The Swiss Civil Code, "Journal of Comparative Legislation and International Law" 1923, t. 5, nr 4, s. 217-219; A.M. Falkowska [Moszyńska], op. cit., s. 57-58; E.F. Malaspina, Introduction to Swiss Civil Law. The History of the Swiss Civil Code, Zürich 2018, s. 7-12 (https://www.ius.uzh.ch/ dam/jcr:2b247c70-ee4f-4bc4-8495-4555e53f050a/History\%20of\%20ZGB_HS18\%20(Fiocchi).pdf (20.03.2021). 
Jak pisał główny referent kodeksu zobowiązań Roman Longchamps Bérier:

(...) zwyciężył jedyny, moim zdaniem, słuszny pogląd, że polski kodeks zobowiązań powinien być etapem rozwojowym prawa, dotychczas na ziemiach polskich obowiązującego, a zatem pewnego rodzaju kompromisem między syntezami Kodeksu Napoleona, austriackiego i niemieckiego tak, aby można go wprowadzić bez wielkich trudności we wszystkich dzielnicach państwa i aby żadna nie miała wrażenia, że jej się narzuca prawo innej dzielnicy ${ }^{22}$.

Podobnie uważał współreferent Ludwik Domański: „kodeks zobowiązań jest przede wszystkim ustawą unifikacyjną, syntezą przepisów kodeksowych, obowiązujących na terenie Państwa Polskiego, a więc kodeksów cywilnych: niemieckiego, austriackiego, francuskiego i rosyjskiego, zaliczanych do różnych systemów"23.

Warto przypomnieć stanowisko A. Falkowskiej, która stwierdziła, że „wszystkie instytucje tego kodeksu, każdy artykuł i paragraf, opierały się na prawie obcym"24. Mówiąc o prawie obcym, z którego korzystali autorzy kodeksu zobowiązań (k.z.), należy wymienić przede wszystkim niemiecki kodeks cywilny z 1896 r. (Bürgerliches Gesetzbuch - BGB), kodeks cywilny austriacki z 1811 r., (Allgemeines Bürgerliches Gesetzbuch - ABGB), Kodeks Napoleona z 1804 r. -KN, w mniejszym stopniu Tom X Zwodu Praw z 1835 t. (Свод законов). Oprócz kodeksów, które obowiązywały na terenie II Rzeczypospolitej, autorzy k.z. korzystali również ze szwajcarskiego kodeksu cywilny z 1907 r. (Zivilgesetzbuch - ZGB), a zwłaszcza jego księgi piątej, czyli kodeksu zobowiązań (Code des obligations, Obligationenrecht), francusko-włoskiego projektu Komitetu Zjednoczenia Ustawodawczego Narodów Sprzymierzonych i Zaprzyjaźnionych (Comite pour l'union legislative entre les nations alliees at amies) ${ }^{25}$, ale tak-

22 R. Longchamps Bérier, Zjednoczenie prawa obligacyjnego w państwach słowiańskich. Referat na I Zjeździe Prawników Państw Słowiańskich w Bratysławie, „Przegląd Prawa i Administracji” 1933, s. 133.

23 L. Domański, System kodeksu zobowiązań, „Nowy Kodeks Zobowiązań” 1934, nr 4, s. 15.

24 A.M. Falkowska [Moszyńska], Wplyw praw obcych..., s. 81.

25 W okresie międzywojennym rozwinęła się idea międzynarodowej unifikacji prawa zobowiązań. W tym celu Francja i Włochy powołały specjalny komitet, którego zadaniem było opracowanie projektu wspólnej ustawy o prawie obligacyjnym. Najważniejszymi autorami projektu byli profesorowie Henri Capitant i Vittorio Scjaloja. Projekt ukazał się w 1927 r. i spotkał się z zainteresowaniem członków Sekcji Prawa Cywilnego Komisji Kodyfikacji pracujących nad kodeksem zobowiązań Sam projekt wspólnego kodeksu miał jednak charakter przede wszystkim unifikacyjny i nigdy nie wszedł w życie. Zob. R. Longchamps Bérier, L’unification internationale du droit des obligations, „Revue polonaise de legislation civile et criminelle” 1929, t. 2; idem, Ujednolicenie prawa obligacyjnego państw słowiańskich, „Przegląd Prawa i Administracji” 1933; L. Górnicki, Prawo cywilne..., s. 399; idem, Wplyw obcych ustawodawstw..., s. 65; A.M. Falkowska [Moszyńska], W kierunku wspólnego kodeksu zobowiązań: projekt francusko-włoski z 1927 r., [w:] Koncepcja integracji w Europie w XX i XXI wieku, t. 2: Prawo, stosunki międzynarodowe, red. D. Bunikowski R. Musiałkiewicz, Toruń 2008; eadem, Wplyw praw obcych na..., s. 82-83; eadem, Międzynarodowe ujednolicenie prawa zobowiq- 
że uwzględniali w swoich pracach rosyjski projekt z 1900 r., kodeks sowiecki, kodeks japoński, kodeks serbski, kodeks portugalski czy prawo czechosłowac$\mathrm{kie}^{26}$.

Nie sposób wskazać, którego kodeksu normy wywarły największy wpływ na kodeks zobowiązań. Jak pisałem wyżej, starano się zachować równowagę pomiędzy systemami (germańskim i romańskim). Choć przepisy k.z. wzorowane były na prawie obcym, to jednak nie mamy tu do czynienia $\mathrm{z}$ recepcją prawa, lecz wykorzystaniem poszczególnych instytucji prawnych ${ }^{27}$. W niniejszej pracy ograniczymy się do wykorzystania przez Komisję Kodyfikacyjną niemieckiego kodeksu cywilnego z 1896 r. (BGB).

Jak wiadomo BGB był najmłodszym kodeksem cywilnym obowiązującym na terenach Polski przed odzyskaniem niepodległości. W związku z tym, że tematyka pracy skupia się na wykorzystaniu w pracach Komisji Kodyfikacyjnej II RP niemieckiego kodeksu, aniżeli na samym kodeksie, chciałbym tylko zwrócić uwagę na jego ogólną charakterystykę, która miała wpływ na to, dlaczego autorzy kodeksu zobowiązań korzystali tak często właśnie z BGB. Zalicza się on to tzw. wielkich kodyfikacji. W przeciwieństwie do Kodeksu Napoleona (Code civile) czy ABGB stoi na stanowisku solidarnościowych poglądów, które rozwinęly się w II poł. XIX w. Przyjmuje systematykę pandektą. Korzysta z rozwiniętej nowoczesnej terminologii oraz klauzul generalnych, będąc wolnym od kazuistyki. Z całą pewnością o tym, jak wielkim osiągnięciem niemieckiej cywilistyki był BGB świadczy jego uznanie nie tylko w Niemczech, ale także, czy może nawet przede wszystkim, poza granicami II Cesarstwa Niemieckiego. Otóż, spotkał się on z zainteresowaniem w Europie, Ameryce Łacińskiej i Azji ${ }^{28}$. Jak wskazała K. Sójka-Zielińska: „Pojawienie się BGB w poważniej

zań w okresie międzywojennym, „Studia Iuridica Toruniensia” 2012, t. 11; D. Deroussin, Code des obligations et des contrats franco-italien de 1927 : chant du cygnet de la culture juridique latine?, "Clio Themis. Revue electronique d'histoire du droit" 2009, nr 2.

26 Zob. Komisja Kodyfikacyjna. Podsekcja Prawa Cywilnego, t. 1, z. 2: Projekt części szczególnej prawa o zobowiązaniach w opracowaniu referentów głównych projektu Ernesta Tilla i Romana Longchamps Bérier, s. 69; R. Longchamps Bérier, Uzasadnienie projektu Kodeksu Zobowiązań, t. 1, Warszawa 1936, s. 287, 315; idem, Uzasadnienie projektu Kodeksu Zobowiąań z. 7, Warszawa 1937, s. 35, 60, 71-72, 87-88; idem, Uzasadnienie projektu Kodeksu Zobowiązań z. 8, Warszawa 1939, s. 148-149 i 159; A.M. Falkowska [Moszyńska], Szwajcarski kodeks..., s. 59.

27 A.M. Falkowska [Moszyńska], Wplyw praw obcych..., s. 81-83.

28 Zob. E. Freund, The New German Civil Code, "Harvard Law Review" 1900, t. 13, nr 8; W.W. Smithers, The German Civil Code, "The American Law Register" 1902; R. Zimmermann, The New German Law of Obligation, New York 2005, s. 5-30; P.R. Luney Jr., Traditions and foreign influences: systems of law in China and Japan, "Law and contemporary problems" 1989, t. 52, s. 130-132; idem, The German Civil Code and the Development of Private Law in Germany, „Oxford U Comparative L Forum” 2006 [https://ouclf.law.ox.ac.uk/the-german-civil-code-and-the-development-of-private-law-in-germany]; R. Berkowitz, Bürgerliches Gesetzbuch (BGB) of 1900: Positive Legal Science and the End of Justice, [w:] The Gift of Science. Leibniz and the Modern Legal Tradition, Cambridge (Massachusetts) 2005, s. 137-156; K. Sójka-Zielińska, Wielkie kodyfikacje cywilne. Historia i współczesność, Warszawa 2009, s. 275-369. 
mierze ograniczyło absolutną dotychczas dominację Code civil w Europie i świecie"29. Szczególny wpływ wywarł niemiecki kodeks cywilny na szwajcarski kodeks cywilny (ZGB) z 1907 r. W polskiej literaturze jako wzór wskazuje się właśnie kodeks szwajcarski, ponieważ stanowił on największe osiągnięcie europejskiej cywilistyki oraz zawierał elementy zarówno germańskie jak i romańskie ${ }^{30}$.

Warto dokonać analizy kodeksu zobowiązań w celu ustalenia, które jego elementy były wzorowane na niemieckim kodeksie cywilnym (BGB). W swoich pracach o kodeksie zobowiązań L. Górnicki wskazał, iż na BGB wzorowano w szczególności: przepisy o zobowiązaniach przemiennych, przepisy o nienależytym wykonaniu zobowiązań, zasady oświadczenia woli składania oferty przy zawieraniu umów, przepisy o zadatku, budowę części szczególnej kodeksu, najem i dzierżawę, przepisy o umowie pośrednictwa, przepisy o umowie spółki cywilnej oraz samo ujęcie treści zobowiązania (art. 17, 29, 37, 55, 68, 94 §2, 189, 194, 207, 200 k.z.) $)^{31}$. Jednocześnie wrocławski historyk prawa zwrócił uwagę, iż przykłady wpływu obcych kodeksów można mnożyć ${ }^{32}$. Korzystając z uzasadnienia do kodeksu zobowiązań autorstwa R. Longchamp Bérier, piśmiennictwa, a nade wszystko tekstów samych aktów normowanych, możemy ustalić, które jeszcze przepisy polskiego prawa obligacyjnego były oparte na niemieckim kodeksie cywilnym. W celu zaprezentowania wykorzystania przepisów BGB w opracowaniu k.z., chciałbym zaproponować na potrzeby niniejszej pracy podział przepisów polskiego kodeksu na trzy kategorie.

Pierwsza grupa to przepisy k.z. wzorowane bezpośrednio na BGB, oczywiście $\mathrm{z}$ ewentualnymi poprawkami. Uwzględniając przepisy wskazane przez L. Górnickiego możemy do niej zaliczyć: odpowiedzialność solidarną wierzycieli (art. 19-21 k.z.), wady oświadczenia woli, brak zamiaru zawarcia umowy (art. 33 k.z.), ziszczenie warunku (art. 48 k.z.), wybór świadczenia przez osobę trzecią (art. 59 k.z.), zastrzeżenie prawa odstąpienia w umowie (art. 76 k.z.), skutki odstąpienia od umowy (art. 78 k.z. i 79 k.z.), zawarcie umowy przez przedstawiciela oraz przedstawicielstwa (art. 93-94 k.z.), odwołanie pełnomocnictwa (art. 98 k.z.), wyłączenie odpowiedzialności za własne czyny - obrona konieczna (art. 139 k.z. i 140 k.z.), nieodstępowania prawa do odszkodowania osobom trzecim (art. 167 k.z.), stosowanie odpowiednie przepisów o przelewie wierzytelności (art. 176 k.z.), wykonywanie zobowiązań (art. 189 k.z.), prawo zatrzymania (art. 219 k.z.), nieważność dokumentów na okaziciela (art. 226 k.z.), nabycie rzeczy

29 K. Sójka-Zielińska, op. cit., s. 300.

30 A.M. Falkowska [Moszyńska], Szwajcarski kodeks..., s. 58-59; Por. K. Dunin, Nowy kodeks cywilny szwajcarski, „Gazeta Sądowa Warszawska” 1908, nr 45; H. Konic, Nowe prawo o zobowiązaniach w Szwajcarii, „Gazeta Sądowa Warszawska” 1912, nr 24; K. Zweigert, H. Kötz, op. cit., s. 166-175.

31 L. Górnicki, Prawo cywilne w pracach..., s. 460-461.

32 Idem, Wplyw obcych..., s. 67. 
tego samego gatunku przez wierzyciela na koszt dłużnika (art. 246 k.z.), stosowanie przepisów o zarachowaniu przy potrąceniu (art. 257 k.z.), bieg terminu przedawnienia wobec osób niemających zdolności do czynności prawnych (art. 278 k.z.), przerwanie biegu terminu przedawnienia (art. 280 k.z.), ustalenie przez sąd ceny w umowie sprzedaży (art. 297 k.z.), szkoda wynikająca z niewłaściwego dostarczenia towaru (art. $301 \$ 3$ k.z.), obowiązek sprzedawcy przekazania informacji kupującemu o przedmiocie sprzedaży (art. 302 k.z.), wyłączenie odpowiedzialności sprzedawcy nieruchomości za wady publiczno-prawne (art. 311 k.z.), rękojmia za wady prawne papierów wartościowych (art. 312 k.z.), termin odstąpienia od umowy sprzedaży (art. 326 k.z.), prawo pierwokupu w umowie odkupu (art. 348 k.z.), przepisy w przedmiocie i niepodzielności prawa pierwokupu (art. 349 k.z. i 350 k.z.), zwrot pożyczki w przypadku nieoznaczenia terminu (art. 439 k.z.) ${ }^{33}$.

Do drugiej grupy możemy zaliczyć przepisy wzorowane na rozwiązaniach przyjętych w BGB oraz w ABGB lub ewentualnie w szwajcarskim kodeksie zobowiązań. Dwa pierwsze kodeksy zaliczają się do systemu germańskiego (niemieckiego ${ }^{34}$ ). Trzeci jest osiągnięciem cywilistyki skupiającym rozwiązania germańsko-romańskie. Do tej grupy możemy zakwalifikować przepisy o: zobowiązaniach solidarnych (art. 10 k.z.), nieważności oświadczenia woli (art. 34 k.z.), pozorności oświadczenia woli (art. 35 k.z.), błędzie w oświadczeniu woli (art. 36-38 k.z.), skutkach zniekształcenia oświadczenia woli (art. 44 k.z.), pierwotnej niemożność świadczenia (art. 57 k.z.), nieważności umowy o spadek po osobie żyjącej (art. 58 k.z.), przepisy o zwarciu umowy (art. 61 k.z. i 63 k.z.), odstępnym (art. 80 i 81 k.z.), niemożności żądania zwrotu świadczenia (art. 131 k.z.), niesłusznym wzbogaceniu (art. 123-127 k.z.), czynach niedozwolonych (art. 134-137 k.z.), solidarnej odpowiedzialności za wyrządzenie szkody i roszczenie zwrotne do sprawcy (art. 146 i 147 k.z.), odpowiedzialności za uszkodzenie ciała lub wywołanie rozstroju zdrowia (art. 165 k.z.), przelewie wierzytelności (art. 170-172 k.z.), zmianie dłużnika (art. 182 k.z.), miejscu spełnienia świadczenia (art. 190 k.z.), terminie spełnienia świadczenia (art. 192 k.z.), prawie żądania pokwitowania spełnienia świadczenia (art. 220 i 221 k.z.), wystawieniu dokumentu na okaziciela (art. 225 k.z.), zwolnieniu dłużnika z zobowiązania (art. 228 k.z.), dokumentach na okaziciela (art. 229 k.z. i 230 k.z.), zwłoce wierzyciela (231 k.z. i 232 k.z.), niewykonaniu świadczenia przez dłużnika (art. 240 k.z. i 241 k.z.),

33 R. Longchamps Bérier, Uzasadnienie projektu kodeksu zobowiąań, t. 1, s. 21-23, 31-32, 52-53, 58, 83-84, 110-111, 126-128, 135-137, 202-205, 247, 264, 283-285, 316-317, 338-329, 365-368, 400-402, 443-444 i 447-449; idem, Uzasadnienie projektu kodeksu zobowiązań, t. 2, Warszawa 1937, s. 11-12, 17-19, 20, 41, 43-44, 53, 74-75; idem, Uzasadnienie projektu Kodeksu Zobowiązań, z. 8 Warszawa 1939, s. 190-191.

34 System germański był czasem określany przed autorów k.z. jako system niemiecki. Zob. idem, Uzasadnienie projektu kodeksu zobowiązań, z. 7, s. 56. 
opóźnieniu i zwłoce dłużnika (art. 247 k.z. i 248 k.z.), skutkach niewykonania zobowiązań wzajemnych (art. 250 k.z. i 251 k.z.), umorzeniu przez potrącenie wierzytelności (art. 258 k.z.), ogólne o przedawnieniu (art. 273 k.z. i 274 k.z.), rozpoczęciu biegu przedawnienia (art. 276 k.z.), przerwaniu biegu przedawnienia (art. 279 k.z.), przedawnieniu wierzytelności (art. 287 k.z.), przejściu ciężarów i korzyści na sprzedawcę (art. 304 k.z.), zwolnieniu z rękojmi sprzedawcy (art. 307 k.z.), rękojmi przy sprzedaży według próbki lub wzoru (art. 321 k.z.), odstępnym od umowy (art. 330 k.z.), domniemaniu istnienia wady (art. 334 k.z.), sprzedaży na próbę (art. 339 k.z.), prawie pierwokupu (art. 346 k.z.), odpowiedzialności darczyńcy za szkody (art. 360 i 361 k.z.), obowiązki wynajmującego (375 i 376 k.z.), przepisy o obowiązkach najemcy (art. 382, 383, 388 k.z.), najmie na czas nieoznaczony (art. 392 k.z.), używaniu rzeczy najętej i podnajemie (art. 398 k.z.), oddaniu rzeczy najętej (art. 400 k.z.), zakończeniu dzierżawy (art. 414 k.z.) i sposobie używania rzeczy (art. 422 k.z.) ${ }^{35}$.

W końcu trzecia grupa, która składa się z przepisów wzorowanych nie tylko na BGB, ale także na ustawach zarówno systemu germańskiego, jak i romańskiego, w szczególności Kodeksu Napoleona. Przepisy te są najlepszym przykładem na unifikacyjny charakter kodeksu zobowiązań oraz elementami wspólnymi obu systemów. Na tych kodeksach wzorowano: uchylanie się od skutków oświadczenia złożonego pod wpływem groźby (art. 41 k.z.), roszczenie o uchylanie się od oświadczenia złożonego pod wpływem błędu (art. 43 k.z.), ziszczenie warunku (art. 47 k.z.), odszkodowanie umowne (art. 82-85 k.z.), przepisy o odpowiedzialności za cudze rzeczy (art. 142-145 k.z.), przepisy o odpowiedzialności za szkody wyrządzone przez zwierzęta i rzeczy (art. 148 k.z. i 151 k.z.), zwrot kosztów pogrzebu w przypadku śmierci poszkodowanego (art. 162 k.z.), przelew wierzytelności (art. 168 i 169 k.z.), zarzuty dłużnika w przelewie wierzytelności (art. 174 k.z.), wstąpienie w prawa wierzyciela z mocą ustawy (art. 179 KZ), przepisy o zmianie dłużnika (183-186 k.z. i 188 k.z.), przesłanie wierzytelności (art. 191 k.z.), domniemanie terminu na korzyść dłużnika (art. 200 k.z.), zwolnienie dłużnika z zobowiązania (art. 204 k.z.), przepisy o przedmiocie wykonania zobowiązania (art. 207 k.z., 209 k.z., 211 k.z.), zarachowanie zapłaty (212 k.z., 213 k.z. i 214 k.z.), wykonanie zobowiązań wzajemnych (art. 215-217 k.z.), prawo zatrzymania (art. 218 k.z.), prawo żądania zwrotu dokumentu o zobowiązaniu (art. 222 k.z.), odpowiednie stosowanie przepisów o zwłoce wierzyciela (art. 237 k.z.), odpowiedzialność za niewykonanie lub nienależyte

35 R. Longchamps Bérier, Uzasadnienie projektu kodeksu zobowiązań, t. 1, s. 37-41, 80-82, 185-189, 175-182, 193-200, 212, 244-246, 253-259, 270-272, 285-287, 290-291, 317-320 326-328, 330-333, 332-333, 335-336, 337-338, 353-359, 368-375, 387-388, 402-403, 430-433, 434-438 i 454-456; idem, Uzasadnienie projektu kodeksu zobowiązań, z. 7, s. 21-25, 34-36, 45-50, 55-59, 63-64, 71-73 i 98-101; idem, Uzasadnienie projektu kodeksu zobowiązań, z. 8, s. 126-129, 133-135, 140-141, 144 147-150, 150-156, 167-168 i 178. 
wykonanie zobowiązania (art. 239 k.z.), definicję zwłoki dłużnika (art. 243 k.z.), odroczenie wykonania zobowiązania (art. 256 k.z.), przepisy o potrąceniu (art. 259-262 k.z.), niemożliwość świadczenia (art. 267 k.z.), kapitalizację zaległych świadczeń okresowych (art. 287 k.z.), zaskarżenie czynności dłużnika (art. 288290 k.z.), obowiązek sprzedawcy do rękojmi (art. 306 k.z.), roszczenia kupującego z tytułu rękojmi (art. 314 k.z.), obowiązek kupującego (art. 337 k.z.), wyłączenie stosowania przepisów o darowiźnie (art. 355 k.z.), żądanie zwrotu przysporzenia majątkowego w umowie darowizny (art. 363 k.z.), przepisy o odwołaniu darowizny (art. 365 k.z. i 367 k.z.) ${ }^{36}$.

Na podstawie wyżej ukazanego zestawienia możemy stwierdzić, że autorzy polskiego prawa obligacyjnego bardzo często korzystali z dorobku niemieckiej cywilistyki. Na BGB wzorowano stosunkowo najwięcej przepisów w porównaniu do innych kodeksów. Mimo to, nie można stwierdzić, że kodeks zobowiązań był wzorowany przede wszystkim na prawie niemieckim. Jak już pisałem, stanowił on akt o charakterze unifikacyjnym, dążącym do kompromisu i zachowania równowagi pomiędzy kodeksami cywilnymi obowiązującymi na terenie II Rzeczypospolitej. To, że cieszył się takim uznaniem i zainteresowaniem członków Komisji Kodyfikacyjnej wynika z tego, że był on wówczas, obok ZGB (w tym szwajcarskiego kodeksu zobowiązań), najnowocześniejszym kodeksem cywilnym w Europie, cieszącym się uznaniem zarówno na kontynencie europejskim, jak i daleko poza jego granicami. Łatwo zauważyć w przedstawionym wykazie, że najwięcej przepisów, w których korzystano z BGB to także przepisy oparte na innych ustawach. Co ważne, choć wzorowano poszczególne przepisy oraz instytucje prawne na ich niemieckich odpowiednikach, to jednak niejednokrotnie starano się dostosować rozwiązania niemieckie do potrzeb polskich. Kodyfikatorzy dostrzegali wady poszczególnych rozwiązań i starali się wprowadzić nowe rozwiązania. Potwierdza to teza, iż nie mieliśmy tu do czynienia z recepcją prawa, rozumianą jako przyjęcie cudzych rozwiązań. W celu zobrazowania tego procesu, chciałbym przedstawić kilka przykładów wpływu BGB na przepisy kodeksu zobowiązań.

36 R. Longchamps Bérier, Uzasadnienie projektu kodeksu zobowiązań, t. 1, s. 43-45, 47-50, 56-58, 207-212, 213-219, 240-242, 249-253, 261-263, 266-268, 272-282, 287-290, 294-295, 299-304, 306-309, 309-310, 311-313, 314-316, 320-323, 338, 349-353, 359-363, 397-400, 403-411, 416-420, 454-471; idem, Uzasadnienie projektu kodeksu zobowiązań, z. 7, s. 27-29, 44-45, 60-62, 85-90, 103-106, 107-108 i 111-115. 


\section{Umowne prawo odstąpienia}

Przepisy o umownym prawie odstąpienia kodeksu zobowiązań opierały się na unormowaniach przede wszystkim BGB, w szczególności art. 76, 78 i 79 k.z., natomiast art. 77 na BGB oraz ABGB. Ustawodawstwo zaborcze nie było jednolite w stosunku do instytucji umownego odstąpienia. Kodeks Napoleona stał na stanowisku, że umowa może być rozwiązana tylko za zgodą stron wyrażoną $\mathrm{w}$ odpowiednej klauzuli lub w przypadkach przewidzianych przez ustawę. ABGB przewidywał taką możliwość wyłącznie w przypadkach zastrzeżenia odstępnego oraz jako lex commissoria przy umowach wzajemnych ściśle terminowych ( $\$ 919$ ABGB). Tom X Zwodu Praw nie normował oraz nie zakazywał umownego odstąpienia od umowy ${ }^{37}$. Najdokładniej i najlepiej umowne prawo odstąpienia było uregulowane w niemieckim kodeksie cywilnym, odróżniając tę instytucję od warunku. To za BGB ( $\$ 346$ i 347) przyjęto art. 76 k.z., który w sposób bardziej zwięzły od niemieckiej ustawy wskazywał możliwość zastrzeżenia przez każdą ze stron umownego prawa odstąpienia przy zawieraniu umowy. Z kolei paragraf drugi opracowano na podstawie $\$ 355 \mathrm{BGB}$, który uprawniał stronę umowy do wyznaczenia uprawnionej stronie okresu, po upływie którego prawo odstąpienia wygasa. Możliwość wyznaczenia terminu miała na celu ochronę bezpieczeństwa obrotu oraz interesów strony ${ }^{38}$.

Artykuł 77 k.z. był wzorowany na BGB oraz ABGB. Przepis ten przychylił się do ogólnej zasady występującej w kodeksie zobowiązań, a obecnej również w BGB, która zakłada pozasądowe dokonywanie czynności. Zawiadomienie o odstąpieniu od umowy należało zgłosić drugiej stronie w dowolny sposób. Jedynie gdy wartość przedmiotu zobowiązania wynosiła ponad tysiąc złotych, wówczas konieczne było zawiadomienie $\mathrm{w}$ formie pisemnej. Podobne stanowisko przyjęły przepisy BGB i ABGB ${ }^{39}$. Paragraf 349 BGB stanowił: „odstąpienie od kontraktu dokonuje się oświadczeniem wobec drugiej strony" ${ }^{\prime 4}$. Jeżeli doszło do odstąpienia uznawano (art. 78 k.z.), że umowa nigdy nie została zawarta (skutek ex tunc), a wszystko ma być przywrócone do pierwotnego stanu ${ }^{41}$.

W zakresie szkody wywołanej utratą, uszkodzeniem lub obciążeniem przedmiotu świadczenia (art. 79 k.z.) polski kodeks nie podzielił stanowiska niemieckiego (z \$351 i 352), które uznano za zbyt surowe ${ }^{42}$.

37 R. Longchamps Bérier, Uzasadnienie projektu kodeksu zobowiąań, t. 1, s. 106-107.

38 Ibidem, s. 107-108.

39 Ibidem, s. 108.

40 Niemiecki Kodeks Cywilny obowiązujący od 1-go Stycznia 1900, Bytom 1900, s. 70.

41 R. Longchamps Bérier, op. cit., s. 108.

42 Ibidem, s. 108-109. 


\section{Obrona konieczna i stan wyższej konieczności}

Obrona konieczna polega na odparciu bezpośredniego i bezprawnego zamachu na jakiekolwiek dobro własne lub innej osoby ${ }^{43}$. W kodeksie zobowiązań została uregulowana w art. $139^{44}$, a wcześniej była znana wszystkim ustawodawstwom w zakresie ich jurysprudencji. Kodyfikatorzy zdawali sobie sprawę z granic obrony koniecznej, która może przerodzić się w samosąd. Dlatego art. 139 k.z. do wyłączenia odpowiedzialności wymagał zaistnienia przesłanek bezprawności zamachu oraz tego, aby był bezpośredni tj. „na pomoc sądową lub policyjną nie można było czekać" ${ }^{45}$. Ponadto obrona, która wyrządziła szkodę, musiała być niezbędna, ponieważ bez jej zastosowania nie można byłoby odeprzeć zamachu. Artykuł 139 k.z. był wzorowany na $\$ 227$ BGB $^{46}$ i za nim dopuszczał obronę konieczną zarówno własnego jak i cudzego dobra, nie czyniąc tu żadnej różnicy (podobnie obronę konieczną rozumiano w szwajcarskim kodeksie zobowiązań oraz w fr.-wł. proj. kod.), gdyż jak wskazał R. Longchamps Bérier: „nie można działania z pobudek altruistycznych traktować gorzej od działania z pobudek egoistycznych" ${ }^{47}$.

Podobnie na prawie niemieckim opracowano art. 140 k.z. ${ }^{48}$ regulujący obronę konieczną wobec rzeczy. Ta szczególna forma obrony koniecznej występowała tylko w niektórych prawodawstwach zaborczych (prawa obcych) ${ }^{49}$. W organicznym zakresie przewidywało ją prawo rosyjskie, a w ABGB i KN należało odwoływać się do ogólnych rozwiązań określających obronę konieczną. Jedynie BGB przewidywał tę instytucję znaną niemieckiej literaturze jako „Sachwehr”. Wprowadzenie tej normy wiązało się z roszczeniem osoby, która poniosła szkodę wobec osób, które uzyskały na tym korzyść o ich zwrot w stosunku do doznanej

43 Z. Radwański, A. Olejniczak, Zobowiązania - część ogólna, Warszawa 2016, s. 201.

44 Art. 139 k.z.: Kto działa w obronie koniecznej, odpierając bezpośredni i bezprawny zamach na jakiekolwiek dobro własne lub innej osoby, ten nie odpowiada za szkodę, jaką wyrządził przytem napastnikowi.

45 R. Longchamps Bérier, Uzasadnienie projektu kodeksu zobowiązań, t. 1, s. 203.

$46 \$ 227$ BGB: Czyn nakazany konieczną obroną nie jest bezprawiem. Obrona konieczna jest to taka obrona, jaka jest potrzebna, aby odwrócić obecną bezprawną napaść od siebie samego lub drugiej osoby.

47 R. Longchamps Bérier, Uzasadnienie projektu kodeksu zobowiązań, t. 1, s. 203.

48 Art. 140 k.z.: Kto zniszczył lub uszkodził cudzą rzecz, albo zranił lub zabił cudze zwierzę w celu odwrócenia od siebie lub od innych niebezpieczeństwa, grożącego bezpośrednio od tej rzeczy lub zwierzęcia, ten nie odpowiada za szkodę, jeżeli niebezpieczeństwa sam nie wywołał, a czyn wyrządzający szkodę był konieczny.

49 Art. 224 ustawy o zapobieganiu przestępstw T. XIV oraz art. 684 T. X Zwodu Praw (który to artykuł nie określał czym jest obrona konieczna). W Kodeksie Napoleona i ABGB nie występowała ta instytucja, dlatego należało stosować ogólne przepisy - \$19 i 1306a ABGB. 
szkody (art. 122 k.z.). Polscy kodyfikatorzy przychylili się do postulatów nauki niemieckiej i austriackiej, uznającej zwolnienie od odpowiedzialności za szkodę osoby (sprawcy) broniącej się przed niebezpieczeństwem ze strony rzeczy lub zwierzęcia $^{50}$. W konsekwencji art. 140 k.z. był wzorowany na $§ 228 \mathrm{BGB}^{51}$.

\section{Przedawnienie}

Przepisy o przedawnieniu zostały uregulowane w Tytule IV Dziale VII (art. 276-287) kodeksu zobowiązań. Większość z nich była wzorowana na BGB. Artykuł 278 k.z. ${ }^{52}$ określający przedawnienie wobec osoby niemającej zdolności do czynności prawnych został przyjęty na wzór $\$ 206 \mathrm{BGB}^{53}$. Istniała różnica między rozwiązaniami zawartymi w Kodeksie Napoleona i T. X Zwodu Praw oraz fr.-wł. proj., a tymi z BGB. Te pierwsze wstrzymały bieg przedawnienia wobec osób małoletnich lub ubezwłasnowolnionych do czasu uzyskania przez nich zdolności do czynności prawnych, niezależnie od tego czy mieli przedstawiciela ustawowego. Zdaniem autorów k.z. takie uprzywilejowanie osób bez zdolności do czynności prawnych jest nieuzasadnione, dlatego przychyli się do rozwiązań germańskich (BGB i ABGB), które uznawały przedawnienie tylko wówczas gdy nie ma przedstawiciela ustawowego ${ }^{54}$. Paragraf 2 art. 178 k.z. wprowadzono na wzór ABGB określając, że termin nie może minąć 2 lata po ustaniu przyczyny. Natomiast ostatni paragraf na wzór BGB oraz orzecznictwa austriackiego ${ }^{55}$.

50 R. Longchamps Bérier, Uzasadnienie projektu kodeksu zobowiąań, t. 1, s. 203-205. Por. L. Domański, Instytucje kodeksu zobowiązań. Komentarz teoretyczno-praktyczny: część ogólna, t. 1-2, Warszawa 1936; J. Korzonek, I. Rossenbluth, Kodeks zobowiązań - komentarz, Kraków 1934.

$51 \$ 228$ BGB: Kto uszkadza albo niszczy rzecz obcą, aby odwrócić grożące z jej strony niebezpieczeństwo od siebie albo drugiej osoby, ten nie działa wbrew prawu, jeżeli to uszkodzenie albo zniszczenie rzeczy jest potrzebne do odwrócenia niebezpieczeństw, a szkoda nie pozostaje w rażącym stosunku do niebezpieczeństwa. Jeżeli działający zawinił spowodowaniem niebezpieczeństwa, to jest on zobowiązany do wynagrodzenia szkody.

52 Art. $278 \$ 1$ k.z.: Przedawnienie biegnie przeciwko osobom pozbawionym zdolności do czynności prawnych lub w niej ograniczonym, chociażby osoby te nie miały przedstawiciela ustawowego. $\$ 2$ Jednocześnie termin nie może się skończyć wcześniej, niż po upływie dwóch lat od chwili, gdy ustanowiono przedstawiciela, albo gdy ustała przygnana jego ustanowienia. $\$ 3$ Gdy termin przedawnienia jest krótszy niż dwa lata, bieg przedawnienia rozpoczyna się od chwili ustanowienia.

$53 \$ 206$ BGB: Jeżeli osoba nieprawodzielna albo w prawodzielności ograniczona nie ma prawnego zastępcy, to przedawnienie przeciw niej bieżące nie może się skończyć przed upływem sześciu miesięcy, licząc od chwili, w której ta osoba staje się bez ograniczenia prawodzielną, albo w której ustaje brak zastępstwa. Jeżeli kres przedawnienia wynosi ,mniej jak sześć miesięcy, to wstępuje przeciąg czasu dla przedawnienia wyznaczony w miejsce owych sześciu miesięcy.

54 R. Longchamps Bérier, Uzasadnienie projektu kodeksu zobowiązań, t. 1, s. 443-444. Por. L. Domański, op. cit.; J. Korzonek, I. Rossenbluth, op. cit.

55 Ibidem, s. 444. 
Twórcy kodeksu zobowiązań projektując art. $280^{56}$ również wzięli za przykład regulacje niemieckiego kodeksu cywilnego ${ }^{57}$. Przepis ten normował nowe rozpoczęcie biegu terminu przedawnienia. Powstawało pytanie, czy po przerwaniu biegu terminu przedawnienia przez dane zdarzenie, nowy bieg rozpoczyna się natychmiast po zajściu zdarzenia powodującego przerwanie, czy też istnieje jakiś okres przerwy, po którym rozpoczyna się bieg przedawnienia. Tylko w BGB zostało to wyraźnie uregulowane ${ }^{58}$. Kodeks ten wprowadzał przerwę przedawnienia w przypadkach wskazanych $\mathrm{w}$ ustawie - wniesienia pozwu, przypozwania, podniesienia zarzutu potrącenia w procesie lub zgłoszenia wierzytelności $\mathrm{w}$ postępowaniu upadłościowym ${ }^{59}$. Kodeks zobowiązań przyjął to stanowisko, precyzując $\mathrm{w} \$ 2$ i 3 moment, w którym bieg przedawnienia rozpoczynał się na nowo.

\section{Podsumowanie}

Problematyka unifikacji i kodyfikacji prawa obligacyjnego oraz samego kodeksu zobowiązań nadal zasługuje na uwagę historyków prawa oraz znawców komparatystyki prawniczej. Stanowi ciekawy przedmiot badawczy dotyczący przenikania się norm prawnych różnych, w tym odmiennych systemów prawnych. Jak wskazywał W. Dajczak kodeks zobowiązań jest interesującym i cennym przedmiotem do badań porównawczych ${ }^{60}$. Kodeks zobowiązań był bez wątpienia osiągnięciem polskiej cywilistyki, łączący w sobie elementy systemu germańskiego i romańskiego. Jak pisali jego autorzy oraz współcześni znawcy przedmiotu był dziełem o charakterze unifikacyjnym, a więc ujednolicającym pozaborowe ustawodawstwo. Dzięki temu żaden z kodeksów cywilnych obowiązujących na ziemiach polskich nie został ani recypowany ani też normy żadnego kodeksu nie zostały w dominującym zakresie przyjęte do polskiego kodeksu. Na podstawie wykazanych w pracy ustaleń, możemy wskazać, że niemiecki kodeks cywilny był jedną z najczęściej wykorzystywanych obcych ustaw. Część przepisów była wzorowana wyłącznie na BGB, inne na BGB oraz ustawach systemu germańskiego, a w końcu na BGB oraz innych ustawach zarówno sytemu romańskiego jak i germańskiego. Co ważne, k.z. nie przyjmował przepisów

56 Art. 280 k.z.: $\$ 1$ Po każdym przerwaniu bieg przedawnienia rozpoczyna się na nowo. \$2 Jeżeli przerwanie nastąpiło przez wniesienie pozwu, przypozwanie lub podniesienie zarzutu potrącenia w procesie, bieg przedawnienia rozpoczyna się na nowo dopiero od chwili prawomocnego rozstrzygnięcia lub innego zakończenia sporu. Jeżeli postępowanie uległo zawieszeniu na zgodny wniosek obu stron, albo wskutek niestawiennictwa obu stron lub jednej z nich, bieg przedawnienia rozpoczyna się na nowo z chwilą zakończenia tego postępowania.

57 Zob. \$212-220 BGB.

58 R. Longchamps Bérier, Uzasadnienie projektu kodeksu zobowiązań, t. 1, s. 6

59 Ibidem, s. 447-448.

60 W. Dajczak, op. cit., s. 828 i n. 
BGB, ani też żadnej innej ustawy wprost. Nie ma tu mowy o recepcji prawa, a jedynie adaptacji, wzorowaniu i wykorzystaniu rozwiązań obcych kodeksów. Co więcej, nawet korzystając wyłącznie z dorobku BGB członkowie Komisji Kodyfikacyjnej dokonywali analizy jego rozwiązań, oceniając ich wartość praktyczną. BGB wielokrotnie bardzo obszernie, niemal kazuistycznie, normował pewne zagadnienia, co dostrzegali autorzy kodeksu. Przykładem mogą być przepisy o umownym prawie odstąpienia.

Mimo coraz bogatszej literatury historycznoprawnej wciąż brakuje, w mojej ocenie, jednej pracy kompleksowo omawiającej historię kodeksu zobowiązań. Choć mamy, m.in. dzięki L. Górnickiemu szereg prac na temat prac kodyfikacyjnych (unifikacyjnych) oraz liczne mniejsze publikacje różnych badaczy poświęcone samemu kodeksowi, zarówno w okresie międzywojennym, jak i w czasach Polski Ludowej, to jednak wciąż nie ma w polskiej literaturze obszernej monografii poświęconej sensu stricto k.z. W ramach takiej pracy, można omówić zarówno prace kodyfikacyjne (unifikacyjne), stosowanie i przyjęcie kodeksu przez orzecznictwo oraz doktrynę, jak i jego obowiązywanie po II wojnie światowej oraz wpływ na Kodeks cywilny z 1964 r. ${ }^{61}$ Przy ewentualnych pracach badawczych należałoby zwrócić uwagę na wpływ obcych systemów prawnych na polskie prawo obligacyjne oraz ewolucję poszczególnych instytucji zaczerpniętych z tych systemów. Warto wreszcie, zainteresować badaczy zagranicznych, w tym zwłaszcza niemieckich, tematyką wpływu BGB na kodeks zobowiązań, jak i całe polskie prawo prywatne, co może zaowocować w pełni prawnoporównawczymi rezultatami.

\section{Bibliografia}

\section{Źródła}

Allgemeines Bürgerliches Gesetzbuch: ABGB - Powszechna Ksiega Ustaw Cywilnych (Austriacki Kodeks Cywilny), red. J. Olszewski i inni, Rzeszów 2014.

Mączyński A. (wstęp), Kodeks Napoleona, Kodeks cywilny Królestwa Polskiego, Kodeks zobowiazań i inne i inne przepisy obowiązujace $w$ województwach centralnych, Warszawa 2008.

Komisja Kodyfikacyjna Rzeczypospolitej Polskiej. Sekcja Prawa Cywilnego, t. 1, z. 1, Projekt prawa o zobowiazaniach w opracowaniu koreferenta projektu Adwokata Ludwika Domańskiego, Warszawa 1927.

Niemiecki Kodeks Cywilny obowiazujacy od 1-go Stycznia 1900, Bytom 1900.

Longchamps Bérier R., Projekt francusko-włoski o zobowiazaniach z r. 1927, Warszawa 1929.

$\overline{61}$ Ustawa z dnia 23 kwietnia 1964 r. - Kodeks cywilny (Dz.U. 1964 nr 16, poz. 93). 
Rozporządzenie Prezydenta Rzeczypospolitej z dnia 27 października 1933 r. - Kodeks zobowiązań (Dz.U. 1933 nr 82, poz. 598).

Rozporządzenie Rady Ministrów z dnia 22 kwietnia 2003 r. w sprawie organizacji i trybu działania Komisji Kodyfikacyjnej Prawa Cywilnego.

Till E., Longchamps Bérier R., Polskie prawo zobowiązań. (Część szczególna). Projekt wstępny z motywami, Lwów 1928.

Ustawa z dnia 23 kwietnia 1964 r. - Kodeks cywilny (Dz.U. 1964 nr 16, poz. 93).

Ustawa z dnia 3 czerwca 1919 r. o powołaniu Komisji Kodyfikacyjnej (Dz.Pr.P.P. 1919 nr 44, poz. 315).

Zarządzenie nr 227 Prezesa Rady Ministrów z dnia 23 sierpnia 1956 r. w sprawie powołania Komisji Kodyfikacyjnej (M.P. 1956 nr 70, poz. 856).

\section{Literatura przedmiotu}

Ault H.J., Glendon M.A., The importance of comparative law in legal education: United State Goals and Methods of legal comparison, "Journal of Legal Education" 1976, t. 27, nr 4.

Berkowitz R., Bürgerliches Gesetzbuch (BGB) of 1900: Positive Legal Science and the End of Justice, [w:] The Gift of Science. Leibniz and the Modern Legal Tradition, Cambridge (Massachusetts) 2005.

Borkowska-Bagieńska E., O doświadczenia kodyfikacji prawa cywilnego w II Rzeczypospolitej dla współczesnego ustawodawcy, „Czasy Nowożytne” 2002, t. 12.

Borkowska-Bagieńska E., Między zbiorem a kodeksem. Refleksje o kodyfikacji i myśli kodyfikacyjnej Oświadczenia, [w:] Historia integra. Księga pamiątkowa ofiarowana prof. Stanisławowi Salmonowiczowi w siedemdziesięciolecie urodzin, red. D. Jancka, R. Łaszewski, Toruń 2001.

Dajczak W., Kodeks zobowiązań jako lekcja metody prawnoporównawczej, „Kwartalnik Prawa Prywatnego" 2014, z. 4.

Derek M., Indywidualizm czy socjologizm? Zasada swobody umów w projektach polskiego kodeksu zobowiązań z 1933 roku na tle porównawczym, „Czasopismo Prawno-Historyczne" 2015, t. 67, z. 2.

Deroussin D., Code des obligations et des contrats franco-italien de 1927 : chant du cygnet de la culture juridique latine?, „Clio Themis. Revue electronique d'histoire du droit" 2009, nr 2.

Domański L., System kodeksu zobowiązań, „Nowy Kodeks Zobowiązań” 1934, nr 4.

Domański L., Instytucje kodeksu zobowiązań. Komentarz teoretyczno-praktyczny: część ogólna, t. 1-2, Warszawa 1936.

Dunin K., Nowy kodeks cywilny szwajcarski, „Gazeta Sądowa Warszawska” 1908, nr 45.

Falkowska [Moszyńska] A.M., Charakter i zakres odpowiedzialności sprzedawcy z tytułu rękojmi w kodeksie zobowiąań z 1933 r., „Zeszyty Naukowe Wyższej Szkoły Suwalsko-Mazurskiej im. Papieża Jana Pawła II w Suwałkach” 2008, t. 9, nr 17.

Falkowska [Moszyńska] A.M., O pracach kodyfikacyjnych słów kilka: prace nad kształtem instytucji rękojmi w kodeksie zobowiązań, [w:] Świat, Europa, mała Ojczyzna, 
studia ofiarowane profesorowi Stanisławowi Grodziskiemu w 80-lecie urodzin, red. M. Małecki, Bielsko-Biała 2009.

Falkowska [Moszyńska] A.M., Międzynarodowe ujednolicenie prawa zobowiązań w okresie międzywojennym, „Studia Iuridica Toruniensia” 2012, t. 11.

Falkowska [Moszyńska] A.M., Szwajcarski kodeks zobowiązań w pracach Komisji Rzeczypospolitej w okresie dwudziestolecia międzywojennego, „Studia Iuridica Toruniensia" 2008, t. 4.

Falkowska [Moszyńska] A.M., W kierunku wspólnego kodeksu zobowiązań: projekt francusko-włoski z 1927 r., [w:] Koncepcja integracji w Europie w XX i XXI wieku, t. 2, Prawo, stosunki międzynarodowe, red. D. Bunikowski, R. Musiałkiewicz, Toruń 2008.

Falkowska [Moszyńska] A.M., Wpływ praw obcych na kodeks zobowiązań z 1933 roku na podstawie wybranych instytucji prawa obligacyjnego, [w:] Korzenie i tradycje współczesnego prawa cywilnego w zjednoczonej Europie, red. A. Karabowicz, M. Strusa, Kraków 2005.

Falkowska-Szemta [Moszyńska] A.M., Regulacja w zakresie odpowiedzialności sprzedawcy z tytuły rękojmi za wady i braki przedmiotu świadczenia $w$ austriackim kodeksie cywilnym z 1811 r. (ABGB) i jego wpływ na przepisy polskiego kodeksu zobowiązań z 1933 r., „Zeszyty Naukowe Wyższej Szkoły Suwalsko-Mazurskiej im. Papieża Jana Pawła II w Suwałkach” 2006, t. 7, nr 14.

Fierich F.X., Komisja Kodyfikacyjna w Rzeczypospolitej Polskiej, „Ruch Prawniczy, Ekonomiczny i Społeczny" 1925, z. 3.

Fierich F.X., Rzut oka na najważniejsze zadania prac kodyfikacyjnych, „Kwartalnik Prawa Cywilnego i Karnego" 1919, R. II.

Freund E.,, The New German Civil Code, "Harvard Law Review" 1900, t. 13, nr 8.

Gordley J, Comparative Law and Legal History, [w:] The Oxford Handbook of Comparative law, red. M. Reimann, R. Zimmermann, New York 2006.

Gordley J., Comparative Legal Research: Its Function in the Development of Harmonized Law, “,The American Journal of Comparative Law” 1995, t. 43, nr 4.

Górnicki L., Godność osobista pracownika pod rządami kodeksu zobowiązań z 1933 r., [w:] Honor, cześć, godność: aspekty historyczno-prawne, red. P. Wiązek, Wrocław 2016.

Górnicki L., Komisja Kodyfikacyjna II RP: pozycja ustrojowa, podejmowanie decyzji, „Acta Universitatis Wratislaviensis. Prawo” 2019.

Górnicki L., Metoda opracowania i koncepcja kodeksu zobowiązań z 1934 roku, „Acta Universitatis Wratislaviensis. Prawo" 2008.

Górnicki L., Organizacyjne zagadnienia kodyfikacji prawa handlowego w Komisji Kodyfikacyjnej II RP (1919-1939), „Acta Universitatis Wratislaviensis. Prawo” 2003.

Górnicki L., Pogranicza systemów prawnych, w szczególności pozaborowych, w pracach nad kodyfikacjami prawa cywilnego i handlowego w II RP, ,,Acta Universitatis Wratislaviensis. Prawo" 2017.

Górnicki L., Prawo cywilne w pracach Komisji Kodyfikacyjnej, Wrocław 2000.

Górnicki L., Prawo jako czynnik integracji państwa w latach II Rzeczypospolitej, „Acta Universitatis Wratislaviensis. Prawo" 2011. 
Górnicki L., Rola parlamentu w powstaniu i działalności Komisji Kodyfikacyjnej II RP $w$ zakresie kodyfikacji prawa prywatnego, [w:] Zgromadzenia stanowe i organy przedstawicielskie w dziejach; Ksiega jubileuszowa dedykowana Profesorowi Marianowi Ptakowi, red. J. Koredczuk, P. Wiązek, Wrocław 2020.

Górnicki L., Wpływ obcych ustawodawstw i doktryny prawa na polska kodyfikacje prawa prywatnego w Drugiej Rzeczypospolitej, „Zeszyty Prawnicze TBSP UJ” 2005, z. 13.

Górnicki L., Zagadnienia systematyki kodyfikacji prawa cywilnego i handlowego w pracach Komisji Kodyfikacyjnej (1919-1939), „Kwartalnik Prawa Prywatnego” 2004, z. 3.

Górnicki L., Zasada uspołecznienia pewnych stosunków umownych w kodeksie zobowiazań z 1933 roku, [w:] Zasady prawne w dziejach prawa publicznego i prywatnego, red. M. Podkowski, Wrocław 2015.

Grodziski S., Komisja Kodyfikacyjna Rzeczypospolitej Polskiej, „Czasopismo Prawno-Historyczne" 1981, t. 31, z. 2.

Grodziski S., Prace nad kodyfikacja i unifikacja polskiego prawa prywatnego (1919-1947), „Kwartalnik Prawa Prywatnego” 1992, z. 1-4.

Grodziski S., W osiemdziesięciolecie Komisji Kodyfikacyjnej (Geneza i struktura), „Państwo i Prawo" 2000, z. 4.

Grodziski S., Z dziejów unifikacji prawa prywatnego, „Czasopismo Prawo-Historyczne” 1985, z. 2.

Halberda J., Instytucja niestusznego zbogacenia w Kodeksie zobowiązań z 1933 r. na tle współczesnych kodyfikacji, „Krakowskie Studia z Historii Państwa i Prawa” 2012, nr 5.

Halberda J., Nienależne świadczenie w polskim Kodeksie zobowiązań z 1933 r. na tle porównawczym, „Krakowskie Studia z Historii Państwa i Prawa” 2016, t. 9, z. 1.

Haponiuk D., Uwagi o pracach nad polskim kodeksem zobowiązań z 1933 r. ze szczególnym uwzględnieniem zasady stuszności, „Miscellanea Historico-Iuridica” 2018, t. 17, z. 1.

Hug W., The history of comparative law, "Harvard Law Review” 1932, t. 45, nr 6.

Jastrzębski R., Wpływ polskiej tradycji prawnej na kodyfikacje prawa prywatnego (1919-1939), [w:] Między tradycją a nowoczesnościa. Prawo polskie w 100-lecie odzyskania niepodległości, red. Ł. Pisarczyk, Warszawa 2019.

Jaworski W.L., Nowożytny Kodeks Cywilny. Referat na Komisji Kodyfikacyjnej Rzeczypospolitej Polskiej dnia 6 grudnia 1921 r., Kraków 1922.

Jędrejek G., Polski kodeks zobowiązań z 1933 roku powstanie, źródła, znaczenie dla europejskiego prawa obligacyjnego, ,Roczniki Nauk Prawnych” 2001, t. 11, z. 1.

Kaczmarek Z., Marszałkowie Senatu II Rzeczypospolitej, Warszawa 1992.

Kola K., Działalność Komisji Kodyfikacyjnej w obszarze prawa zobowiązań. Refleksje z okazji 80 rocznicy Kodeksu zobowiązań, „Palestra” 2013, nr 9-10.

Konic H., Nowe prawo o zobowiązaniach w Szwajcarii, „Gazeta Sądowa Warszawska” 1912 , nr 24.

Koschembahr-Łyskowski I., W sprawie naszego prawa cywilnego, Warszawa 1925.

Korzonek J., Rossenbluth I., Kodeks zobowiązań - komentarz, Kraków 1934. 
Lityński A., Długa droga kodyfikowania prawa cywilnego w Polsce, „Czasopismo Prawno-Historyczne" 2001, z. 1.

Lityński A., Pół wieku kodyfikacji prawa w Polsce (1919-1969), Tychy 2001.

Lityński A., Wydział Karny Komisji Kodyfikacyjnej II Rzeczypospolitej. Dzieje prac nad częścia ogólną kodeksu karnego, Katowice 1991.

Longchamps Bérier R., L’unification internationale du droit des obligations, „Revue Polonaise de Legislation Civile et Criminelle" 1929, t. 2.

Longchamps Bérier R., Ujednolicenie prawa obligacyjnego państw słowiańskich, „Przegląd Prawa i Administracji” 1933.

Longchamps Bérier R., Uzasadnienie projektu Kodeksu Zobowiązań, z. 1, Warszawa 1936.

Longchamps Bérier R., Uzasadnienie projektu Kodeksu Zobowiązań, z. 7, Warszawa 1937.

Longchamps Bérier R., Uzasadnienie projektu Kodeksu Zobowiązań, z. 8, Warszawa 1939.

Longchamps Bérier R., Zjednoczenie prawa obligacyjnego w państwach słowiańskich. Referat I Zjeździe Prawników Państw Słowiańskich w Bratysławie, „Przegląd Prawa i Administracji” 1933.

Luney P.R. Jr., Traditions and foreign influences: systems of law in China and Japan, "Law and Contemporary Problems" 1989, t. 52.

Malaspina E.F., Introduction to Swiss Civil Law. The History of the Swiss Civil Code, Zürich 2018, https://www.ius.uzh.ch/dam/jcr:2b247c70-ee4f-4bc4-84954555e53f050a/History\%20of\%20ZGB_HS18\%20(Fiocchi).pdf (20.03.2021).

Mazuryk M., Sadowski I., Organizacja i funkcjonowanie komisji kodyfikacyjnej prawa cywilnego w latach 1919-1989. Zarys problematyki, ,Rocznik Nauk Prawnych” 2013, nr 23, z. 1.

Mohyluk M., Porzadkowanie prawa w II Rzeczypospolitej: Komisja Kodyfikacyjna i Rada Prawnicza, „Czasopismo Prawno-Historyczne” 1999, t. 51, z. 1-2.

Moniuszko A., Pomianowski P.Z., Zerwana więź. Tradycje dawnego prawa polskiego w XIX i XX wieku, [w:] Między tradycją a nowoczesnością. Prawo polskie w 100-lecie odzyskania niepodległości, Warszawa 2019.

Petraniuk J.S., Charakterystyka polskiego prawa zobowiązań okresu II Rzeczypospolitej, [w:] Synteza Prawa Polskiego 1918-1939, red. T. Guz, J. Głuchowski, M.R. Pałubska, Warszawa 2013.

Pietrzak M., Z problematyki kodyfikacji prawa w II Rzeczypospolitej, [w:] Partykularyzm a unifikacja prawa w Polsce (XV-XX w.), red. T. Maciejewski, Gdańsk 1994.

Płaza S., Historia prawa w Polsce na tle porównawczym, cz. III, Okres międzywojenny, Kraków 2001.

Płaza S., Kodyfikacja prawa w Polsce międzywojennej, „Czasopismo Prawno-Historyczne" 2005, t. 57, z. 1.

Radwański Z., Kształtowanie się polskiego systemu prawnego w pierwszych latach II Rzeczypospolitej, „Czasopismo Prawno-Historyczne” 1969, t. 21, z. 1.

Radwański Z., Olejniczak A., Zobowiązania - część ogólna, Warszawa 2016. 
Rosett A., Unification, Harmonization, Restatement, Codification and Reform in International Commercial Law, , "The American Journal of Comparative Law” 1992, t. 40 , nr 3.

Salmonowicz S., Kodyfikacje i myśl kodyfikacyjna XVII i XVIII wieku, [w:] Dzieje kodyfikacji prawa. Materiały na konferencję historyków prawa w Karpaczu, Poznań 1974.

Schmitthoff M., The science of comparative law, “The Cambridge Law Journal” 1939, t. $7 \mathrm{nr} 1$.

Schuster E.J., The Swiss Civil Code, "Journal of Comparative Legislation and International Law” 1923, t. 5, nr 4.

Sitnicki Z., Kodyfikacja a unifikacja, „Przegląd Sądowy” 1929, z. 4.

Smithers W.W., The German Civil Code, “The American Law Register” 1902.

Sójka-Zielińska K., Organizacja prac nad kodyfikacja prawa cywilnego w Polsce międzywojennej, „Czasopismo Prawno-Historyczne” 1975, t. 27, z. 2.

Sójka-Zielińska K., Wielkie kodyfikacje cywilne. Historia i współczesność, Warszawa 2009.

Stawarska-Rippel, Kodeks zobowiązań w pierwszych latach Polski Ludowej, „Kwartalnik Prawa Prywatnego" 2004, nr 3.

Sucharitkul S., Unification of Private Law and Codification of International Law, "Uniform Law Review" 1998, t. 3, z. 2-3.

Szafrański W., Pojęcie kodyfikacji w ujęciu historycznym, [w:] Prawo wobec wyzwań współczesności, t. 2, red. P. Wiliński, Poznań 2005.

Uruszczak W., Europejskie kodeksy prawa doby renesansu, „Czasopismo Prawno-Historyczne" 1988, t. 40, 1988, z. 1.

Zimmermann R., The German Civil Code and the Development of Private Law in Germany, „Oxford U Comparative L Forum” 2006, https://ouclf.law.ox.ac.uk/ the-german-civil-code-and-the-development-of-private-law-in-germany, (10.03.202).

Zimmermann R., The New German Law of Obligation, New York 2005.

Zweigert K., Kötz H., An Introduction to Comparative Law. Volume I: The Framework, Amsterdam-New York-Oxford 1977. 
STRESZCZENIE

\section{Niemiecki kodeks cywilny w pracach Komisji Kodyfikacyjnej nad Kodeksem zobowiązań z 1933 r.}

Do największych osiągnięć Komisji Kodyfikacyjnej okresu międzywojennego należy Kodeks zobowiązań z 1933 r. Opracowanie polskiego prawa obligacyjnego było z punktu widzenia gospodarczego i społecznego pilniejsze od innych dziedzin prawa cywilnego. Przygotowując projekt ustawy o prawie zobowiązań, jej twórcy byli w dość dogodnym położeniu. Nie byli związani prawem polskim, rozumianym jako prawo z czasów I Rzeczypospolitej, a ponadto mogli korzystać z rozwiązań poszczególnych praw dzielnicowych. W związku z tym kodeks zobowiązań należy określać jako dzieło o charakterze unifikacyjnym, zachowującym równowagę pomiędzy systemami prawnymi poszczególnych dawnych dzielnic zaborczych. Szczególnie wiele rozwiązań kodeksu zobowiązań wzorowano na niemieckim kodeksie cywilnym (BGB) z 1896 r. Był to, obok szwajcarskiego kodeksu cywilnego w tym jego księgi piątej - kodeksu zobowiązań, najnowocześniejszy kodeks cywilny w Europie i co ważne, najmłodszy, jaki obowiązywał na terenie (zachodnim) Polski. Po dokonaniu analizy kodeksu zobowiązań, BGB, uzasadnienia projektu kodeksu zobowiązań oraz dokonania analizy porównawczej możemy ustalić, które przepisy polskiego kodeksu były opracowane przy wykorzystaniu niemieckiego kodeksu cywilnego. W celu zaprezentowania omawianego zjawiska w pracy został zaproponowany podział przepisów k.z. na trzy grupy. Pierwsza zawiera przepisy wzorowane wyłącznie na BGB. W drugiej znajdują się przepisy wzorowane na BGB oraz innych kodeksach należących do systemu germańskiego tj. ABGB z 1911 r. oraz ewentualnie szwajcarskiego kodeksu zobowiązań, który zawierał rozwiązania zarówno germańskie jak i romańskie. Natomiast trzecia grupa skupia przepisy oparte na ustawach systemu romańskiego (Kodeks Napoleona) oraz germańskiego w tym BGB. Wykaz ten dowodzi unifikacyjnego charakteru i istoty polskiego prawa obligacyjnego. W celu przybliżenia omawianego zjawiska zostało zaprezentowane wykorzystanie przepisów BGB na kilku wybranych przepisach kodeksu zobowiązań dotyczących: umownego odstąpienia od umowy, wyłączenia odpowiedzialności za własne czyny oraz biegu terminu przedawnienia. Omawiana problematyka jest interesująca dla historyków prawa oraz znawców komparatystyki prawniczej, ponieważ unifikacja prawa zobowiązań wiążę się z przenikaniem się norm różnych systemów prawnych. 


\section{SUMMARY}

\section{The German Civil Code in the Work of the Codification Committee on the Code of Obligations of 1933}

One of the greatest achievements of the Codification Commission during the interwar period is the Code of Obligations from 1933. From the economic and social point of view, the development of Polish obligatory law was more urgent than other areas of civil law. During the preparation of the bill about the law of obligations, its authors were in a fairly convenient position. They were not bound by Polish law, understood as the law of the First Republic of Poland, and on the other hand, they could use the solutions of individual district laws. Therefore, the code of obligations should be described as a work of a unifying nature that maintains a balance between the legal systems of individual former partitioning districts. In particular, many solutions in the code of obligations were modelled on the German Civil Code (BGB) from 1896. It was, next to the Swiss Code of Obligations, the most modern civil code in Europe and, importantly, the youngest one that was in force in (western) Polish territories. After analysing the code of obligations, BGB, the justification for a draft of the code of obligations, and performing comparative analysis, we can determine which provisions of the Polish code were developed using the German Civil Code. To present the discussed phenomenon in this paper, a division for three groups of the regulations included in the code of obligations was made. The first contains rules modelled exclusively on the BGB. The second one includes provisions modelled on the BGB and other codes belonging to the Germanic system, i.e. ABGB from 1911, and possibly the Swiss code of obligations, which included both Germanic and Romanesque solutions. On the other hand, the third group includes regulations based on the laws of the Romanesque system (Napoleon's Code) and the Germanic system, including the BGB. This list proves the unification nature and essence of Polish obligation law. To introduce the discussed phenomenon, the use of the BGB provisions was presented on a few selected provisions of the Code of Obligations concerning: contractual withdrawal from the contract, exclusion of liability for one's actions, and the limitation period. The discussed issues are of interest to historians of law and experts in comparative legal studies because the unification of the law of obligations is an excellent example of the use of the norms of various legal systems. 